Rural Sociology 74(1), 2009, pp. 3-24

Copyright (C) 2009, by the Rural Sociological Society

\title{
Democratizing States and the Use of History*
}

\author{
Jess Gilbert \\ Department of Rural Sociology \\ University of Wisconsin-Madison
}

\begin{abstract}
A pervasive anti-statism often blinds us to the democratic victories in the past and thus to possibilities in our future. This article argues that big government can democratize society and uses historical investigation to make the point. The study of history emancipates us from the tyranny of the present. Progressive social change has come about in the United States and elsewhere as combined bottom-up, top-down initiatives. I present two such cases of democratization during the New Deal era. The first is about rural sociologists' participatory-action research with local citizens for policy planning. This program, while short-lived, fed into the creation of the field of community development. The other is a land-reform experiment among poor African Americans. In the 1960s these "resettlement communities" became local strongholds of the civil-rights movement, and their descendants carry on the struggle today. I use these two historical instances to show that big states as well as social scientists have been effective agents of democracy, and suggest that they can be again. History then enable us to reimagine, re-new, and re-form our democratic tradition of rural sociology.
\end{abstract}

What you have as heritage,

Take now as task;

For thus you will make it your own!

-Goethe, Faust (Pelikan 1984:82).

Big government can democratize society. A simple enough thesis, but one that not everybody accepts, especially contemporary social theorists. Even some of you may dispute that modern states can behave historically been-agents of democracy. Max Weber (1978:992, passim; Cohen 1985) disagreed with this position, at least theoretically, as did the New Left of the 1960s and much of the cultural or academic Left more recently (including the old New Left). In particular, Michel

* An earlier version of this article was given as the presidential address to the Rural Sociological Society annual meeting, Manchester, NH, July 28, 2008. This research has been supported by grants from the U.S. Department of Agriculture (via Tuskegee University), the Wisconsin Agricultural Experiment Station, and the University of Wisconsin-Madison Graduate School. I want to thank members of the Mound/Henderson Loop Resettlement Community in Louisiana (especially Mrs. Mabel Walker, Sarah Sims, Glenn Dixon, Ronnie Foster, and Dexter Davis), and to acknowledge crucial assistance from Margaret Christie, Marilyn Sinkewicz, and Spencer Wood. I dedicate this piece to Olaf Larson, from whom I have learned so much about rural sociology, past and present. 
Foucault (1991:102-4; Foucault and Chomsky 1997:129-31) and James Scott (1998) see strong states as forces mainly to resist, besides of course to theorize. They and the others hold that states are no good for fomenting positive social change (Bernstein 1992:31-56; Gordon 1991:5-7, 46-48; Kloppenburg 1994; Rorty 1998). On this point, political conservatives concur with the postmodernists (except for that theory thing). Here I shall develop the opposite thesis, that big states actually have democratized civil society-and therefore can do so again.

\section{What's the Use of History?}

History is useful in making this argument. A pervasive anti-statismwhether of the New Left, or today's cultural Left or Right-blinds us, I believe, to the victories in our past. These include the small successes but lasting legacy of Reconstruction after the Civil War as well as the much larger progressive advances of the 1930s labor movement and the 1960s civil-rights movement and Great Society/War on Poverty. Not that these historical instances achieved all their glorious goals, but they nonetheless should be celebrated and employed in the present. They constituted real progress toward democracy, by which I mean a wider distribution of power and resources in society. These reform episodes illustrate how social change comes about in the United States and elsewhere: as combined bottom-up, top-down initiatives (Rorty 1998:5355; Summers 2003:158-59; Unger and West 1998:51-52).

In this article I present two other cases of democratization, both from the New Deal era but having continuing relevance to the present: one about rural sociologists' action research with local citizens, the other concerning a land-reform experiment among African Americans that goes on today. Here I am following the lead of Couto (1991:289-318), who views the civil-rights movement as combining local "redemptive organizations" and federal "heroic bureaucracies," and Unger and West (1998:20), who speak of progressive reform in light of "an energized majority" and "national leaders." History enables us to claim such inspiring achievements and to use them in our own ongoing struggles.

History, in other words, is about the present; the past is contemporary. As novelist William Faulkner (1951) said, "The past is never dead. It's not even past.' Thus conceived, history becomes

a set of stories we tell in order to understand better who we are and the world we're now in... . Good history makes us think again about the definition of things we thought we knew pretty well, because it engages not just with what is familiar but with what is strange. It recognizes that "the past is a foreign 
country" as well as being our past. (Williams 2005:1, first emphasis added)

History is not dead and gone but rather is present in the here and now. Odd as it sounds, history is also about the future. C. Wright Mills (1959:174) addressed this point in The Sociological Imagination: "We study history to discern the alternatives within which human reason and human freedom can now make history." Claiming an alternative past (whether for rural sociologists, black farmers, or other groups) opens up multiple futures. It stimulates our vision as to possibilities: What once was can be again, or rather may be re-newed and re-gained. History then starts in the present and looks both ways, toward the past and the future. As one writer put it, "looking back promotes thinking forward"' (Thompsett 1999:6).

Not everyone subscribes to this view of history. In 1941, H. Richard Niebuhr (1941:59-73) wrote that history may be grasped from two different angles, either externally or internally. The disengaged pose sees dead things in the past, to be observed, broken down, and added up: dusty documents, abstracted ideas, isolated individuals-impersonalities all. In contrast, the view of history from within is about people, relationships, community, personal commitments. It calls for both memory and hope, a re-presented past and an envisioned future. History thus is the story of our lives. In Achieving Our Country, a history of leftist thought in modern America, Richard Rorty (1998:35-38) makes a similar point, using the terms spectatorial and participatory. Rorty criticizes the U. S. academic or cultural Left since the 1980s for its "theorizations" that lead us to assume the stance of detached spectators rather than active agents. Like Mills, he encourages us to become participants in our own history-history-makers, if you will. If you will.

I turn next to my first case of participatory history. Here I hope to surprise and challenge you about the past, our past. You might be surprised by the radically democratic nature of rural sociologists' theory and practice in the New Deal. Their work at democratization could prompt us to ask ourselves: Are we equally committed to social reform and economic justice? Have we changed the world, as they did? In addition to instructing us, our forebears can also inspire. They participated in one of the few (and earliest) historical examples of a massive social-action program, involving nearly 150,000 farm men and women in participatory research and grass-roots planning. Their work then offers us edification as well as foundation for our tasks now. In some significant ways we have not surpassed them yet. 


\section{Democratizing Rural Sociology in the New Deal}

Most of the New Deal sociologists shared a two-handed commitment to democracy. First, they saw social science and the central state as potential agents of progressive reform. If professionals and politicians worked to extend power and resources beyond the elite to common people, half the democratizing battle was won. Second, these sociologists believed that science must join with folk knowledge or common sense, and that federal authority should decentralize to local citizens. This top-down and bottom-up approach was embodied in New Deal "democratic planning," known more prosaically as county landuse planning. In this section I describe that program and show how rural sociologists worked in it to merge social science with local knowledge on the one hand, and, on the other, to integrate federal action with citizen participation.

The program, which I shall call county planning, was a federal/state organization of grass-roots planning committees. It began late in the New Deal, which by 1938 had proliferated "alphabet agencies" that sometimes worked at cross-purposes. The planning program meant to unify and localize the federal programs at the county level, with leadership by citizen committees. All the agencies it coordinated made deep footprints on the land, especially the Agricultural Adjustment Administration (AAA), which took acres out of use; the Soil Conservation Service (SCS), which physically altered the landscape; and the Farm Security Administration (FSA), which diversified production among the poor. Rural sociologists and others helped organize many county committees of local citizens to advise and "correlate" (as they said) the agencies. Each committee consisted of 10 to 15 farmer-citizens plus the local administrators of the AAA, SCS, FSA, and other agencies. Citizen members represented the different rural communities of the county, which themselves were organized into smaller, neighborhood committees. Thus every farm family fit into some socio-spatial unit that led up to the county committee. Once a county was organized for equal representation-no small ruralsociological task, as I elaborate shortly-the initial goal of the committee was to tailor the current federal programs to fit county needs, as guided by local citizens and administrators working together. Eventually they intended to reform public policy. The county planning program spread rapidly; by 1942 nearly 2,200 counties (two-thirds of all in the U. S.) had such committees, with a total of nearly 150,000 citizenmembers (Gilbert 1996, 2003; Kirkendall 1966:165-92).

Within this late New Deal effort, sociologists played two main roles. Most extensively, they helped set up the planning committees by 
delineating the boundaries of rural neighborhoods and communities, such that the best representation of local citizens obtained. They called this activist research "community delineation.'” With farmer-partners, government sociologists conducted nearly 2,000 community delineations, including 11,000 neighborhood delineations, across 32 states (Bureau of Agricultural Economics [BAE] 1941:8; Loomis and Ensminger 1942:48; Loomis, Ensminger, and Woolley 1941:339). Their other role was more intensive: on-the-ground assessment of the planning program in particular counties. Due to congressional intervention, only a few of these were ever completed, notably Arthur Raper's (1943) participatory evaluation in Greene County, Georgia, to which I return below.

These sociologists were part of the Division of Farm Population and Rural Welfare, a research unit of the U.S. Department of Agriculture's (USDA's) BAE. 1 This "rural sociology" division peaked in numbers and prestige during the early 1940s, with 57 professional researchers (including social psychologists, human geographers, and cultural anthropologists), mostly in seven regional BAE offices (Larson and Zimmerman 2003). One of the most popular was in Berkeley, California. The division head, Carl C. Taylor, wrote to an apparently wayward young researcher in 1943:

You will remember that I used to joke about the people in our West Coast office getting Berkeley-itis and used to define the symptoms as follows: First, once having gotten into the West Coast office, one was never willing to leave the region; second, he even became unwilling to leave California, or even to get very far away from Berkeley; and, third, no matter what focus for work he had when he went there, he shifted that focus to the problem of farm labor. It looks as if you have all the symptoms of Berkeley-itis and I am writing to ask you either to correct my diagnosis or assist me in making a better one. (Taylor 1943)

The work of the rural-sociology division represents the nation's first large-scale attempt to join professional knowledge with local knowledge in public policy. The aim was to democratize the countryside by diffusing power and resources downward to the local citizenry.

As head of the BAE sociology division, Taylor drove these goals home every day. The major rural sociologist of the New Deal, he had studied

\footnotetext{
${ }^{1}$ Until the launch of the county planning program in 1938, the division was known as Farm Population and Rural Life, a name it resumed in 1947.
} 
with radical economist Thorstein Veblen at the University of Missouri and imbibed his historical, institutional approach to science and society. Taylor's own radicalism got him fired in 1931 from North Carolina State College, where he was dean. He led the BAE sociology division from 1935 until 1952, and was president of the new Rural Sociological Society (in 1939) and the American Sociological Society (1946). His presidential address titles alone speak volumes: "Social Theory and Social Action," "Sociology and Common Sense" (Christie 1996; Christie and Gilbert 1995; Larson, Williams, and Wimberley 1999; Larson and Zimmerman 2003). ${ }^{2}$

Reading those speeches tells us even more. In his RSS address, Taylor announced his theme as "developing sociology by doing practical research ... useful to programs of social action." Such "social action" included, of course, New Deal programs. Taylor offered a hypothesis about the rural community: "When the structural and functioning patterns of communities are violated by outside pressure, local resistance develops; when they are used or amplified, local assistance is guaranteed." He is here trying to teach the top-down New Deal some basics of bottom-up organizing-for example, don't enter a community acting as if you have all the answers. Even if you do have the answers (which is doubtful), you will not succeed in "helping" the community. He concluded his talk with a folk saying to spur rural sociologists to public engagement: "It is purely up to us whether we "want to fish, or cut bait." Taylor's own professional preference was that sociology should be "on the spot," that is, in demand and expected to deliver usable knowledge (1940:28, 31, 1937a).

Taylor knew, moreover, that local residents had practical and useful knowledge about their communities. In his presidential address to the American Sociological Society, he urged more joining of social science with common sense, defined as "the knowledge possessed by those who live in the midst and are a part of the social situations and processes which sociologists seek to understand." Such knowledge included political, economic, and cultural insights into their own lives as well as their local areas. Scientists could learn a great deal from their "subjects," not least because people had a working knowledge of their own social milieu. To Taylor, the best social science combined abstract, systematic knowledge and local folk knowledge, or as he put it, "sociology and common sense." He also lamented that students were

\footnotetext{
${ }^{2}$ Much of my understanding of Carl Taylor comes from working with Margaret Christie (1996; Christie and Gilbert 1995). I have also benefitted greatly from numerous discussions with Julie Zimmerman and especially with Olaf Larson; their Sociology in Government (2003) is the definitive history of Taylor's division.
} 
taught otherwise in graduate school: "I have for a long time worried about the fact that it takes young sociologists from five to ten years to recover from what happens to them in their graduate training" (Taylor 1947:1, 8)..$^{3}$

Taylor held "the definite conviction that our various levels of democracy, from local neighborhoods and communities on up, must be tied together in national planning and action, and that unless an American public is created, and created in this fashion, the Federal Government will tend to be an autocratic and not a democratic device for the operation of agricultural programs." This stance exemplifies the complementary top-down, bottom-up approach. In contrast to technocrats then and now, Taylor argued strongly that the planning process must be led more by citizens than by experts. Scientists and technicians must relinquish faith in their "master plans"; "it is more important that social planning be democratic than that it be either comprehensive or logical." By “democratic planning,' Taylor meant a process whereby different types of representatives (farmers, scientists, administrators) come together and work out a "collective solution." Of course, there was never agreement on every point. Where common understanding or "consensus" ended, further unified action could not proceed. Thus the requirement for more discussion and the next meeting (Taylor 1938, 1941b, N.d.).

Democracy, Taylor continued, amounted to "more than an idea; it is a method of action.' It is a type of social organization that encouraged self-governance-not only politically but in the broadest sense of people's participation in decisions affecting their own well-being. This kind of public involvement and citizen planning is what Taylor intended by the frequently used phrase "economic democracy." He assumed that conflicts of interest existed throughout society. What was needed was not just a "majority vote" but a process of "collective bargaining or investigation by the conflicting interests themselves. That is true economic democracy" - a task, Taylor added (as could we), that "in agriculture is still ahead of us." His vision for rural America, in other words, attempted to mediate different interests, including local communities and the federal government as well as scientists and citizens (Taylor N.d., 1937b).

Taylor practiced what he preached. Beginning in 1939, his division became increasingly focused on delineating communities to be

\footnotetext{
${ }^{3}$ Dwight Sanderson, the first president of the RSS, also preceded Taylor as president of the ASS. His address to the latter organization is in some ways even more impressive than Taylor's; see Sanderson (1943).
} 
represented on the county planning committees. In a memorandum intended only for internal use, a BAE sociologist wrote:

The greatest need in every community undertaking planning is for the men, women, and children of the community to form and operate for themselves a functioning organization through which to help themselves... . Rural community organization should be thought of as the means of bringing together the people of the community so that they can think through their common problems, work out ways and means of solving them, and through cooperative effort, develop schemes for carrying through their plans. (BAE 1940:2)

Sounds like community organizing to me! By 1941, as noted above, local citizens and government sociologists had delineated 11,000 rural neighborhoods and 1,800 communities in a majority of the states (BAE 1941:8).

The purpose of community delineation (remember) was to increase representation and participation in the local committees. In the same internal memo quoted above, the BAE sociologist continued: "To make possible real representation and active participation on the part of farm people necessitates having people work in effective social groups which we term communities: that is, areas within which people have the strongest sense of belonging together.' The government sociologists believed that this was best accomplished by people working together in local groups that they already felt attached to-one serviceable definition of "community." For over 25 years, rural sociologists had investigated small communities in excruciating detail. Now, in this delineation work, they were able and eager to apply their accumulated knowledge to practical, representative ends. To the activist sociologists, "community organization" was a verb-an activity to perform, not an object of study. One described this type of participatory research as a "sociology of social action" (BAE 1940:1, 1941:7-10, 18; Dodson, Esnminger, and Woodworth 1940; Ensminger 1940; Wakeley 1941:63).

Several BAE and cooperating land-grant sociologists recorded the procedure used for delineating rural communities. A good example occurred in Kentucky, where Howard Beers, Robin Williams, John Page, and Douglas Ensminger (1941) applied the technique in Garrard County. They first met with the new land-use planning committee, which had requested the sociological-technical assistance. The field work of delineation began with "a systematic visitation of the selected neighborhood residents" who would indicate their area boundaries on a base map. The sociologists asked residents: "If folks from this area 
were in the county seat and were asked where they lived, what would they probably say? Who belongs to this neighborhood [or community]? Who identifies with this area? How far down this road does your community go? Where does the next neighborhood begin? So is this [pointing to the map] the best place to draw the boundaries of your community?" Over the course of such field work, the sociologists delineated the 38 rural neighborhoods and the 9 communities in Garrard County (Beers et al. 1941:152-60). ${ }^{4}$

However, they fully realized that the real experts in the process were the local citizens. Community delineation was a formalization of local knowledge. Beers et al. (1941:154) wrote that their area delineations were "merely those social groupings which to a long-time, widely acquainted resident of [the] county might be obvious." The sociologists thus rationalized common sense. The acquired formal knowledge then advanced equality of representation on the committees. Carl Taylor's vision for rural sociology was here realized: scientists and citizens combined their unique knowledge to promote positive social change, or, as he called it, "planned social action." He noted further: "We trust our findings because the 'folks' who are these communities were our participant observers" (Taylor 1941a:157-58).

What was the local upshot of all this community delineation? Although the program fell short of "democratic planning," it made a good start. Here I only summarize some of the exemplary outcomes in a very poor, bi-racial, plantation area (for more details, see Gilbert 1996 and 2008). Arthur Raper, a rural sociologist in Taylor's division, spent two years documenting the effects of the planning program in Greene County, Georgia. While his Tenants of the Almighty chronicles how the New Deal denied blacks equal treatment, in every chapter Raper notes their (as well as poor whites') massively improved conditions due to the county planning program.

The program drastically increased "balanced diets, health care, better schools, and community participation." For example, the county planning committee was able to enlarge the local Farm Security Administration (FSA), which in turn led to a remarkable jump in the average amount of fruits and vegetables canned by poor families: Compared to scarcely a dozen quarts before getting on the program, an average 225 quarts of produce per family were "put up" in 1939 and an astonishing 499 quarts in 1942. Raper attributed this huge nutritional gain to the federal loans for pressure cookers and demonstrations by

\footnotetext{
${ }^{4}$ For more on the participatory aspects of community-delineation research, see Beers et al. (1941), Dodson et al. (1940), Sanders and Ensminger (1940), and Gilbert (2008).
} 
the FSA home supervisors. The planning program also improved education in Greene County. Twenty-six new school buildings were erected, and teacher qualifications shot up. Even though a rural county, Greene had never had vocational-agricultural and home-economics teachers-until the planning program came in 1939. By 1942, thirteen such teachers had arrived, seven white and six black (Raper 1943:23441, 304-9, 385-86). Moreover, greater access to health care was one of the largest successes, as the county planning committee expanded the nation's first group medical plans-and these for poor people. Raper noted:

The members of the [medical cooperative] like the feeling that is theirs when they send for a doctor, like knowing they have some claim on his services. The doctor is from that prosperous world of colleges, "educated" talk, grapefruit for breakfast and Sunday clothes all week long. In some of the poorer homes he and the FSA supervisor are the only persons from that world who ever come inside the house and sit down and talk. (1943:250)

Overall Raper reported "more activity everywhere," countywide feelings of accomplishment, and "hope, too, on the face of many a farmer-white or black... . A world of things have been done in the past four years. A larger world of things still remain to be done.' For Raper, county planning signaled something worth celebrating and expanding. Admittedly, Greene County was not randomly selected. Rather it was exemplary, "a demonstration area in which county, state, and federal agencies would work together in a new way" (Raper 1943:203-9). Greene illustrated what was possible with cooperative planning-what the county program could accomplish by combining a top-down federal bureaucracy with bottom-up, local citizen organization.

But that achievement did not last long. In 1942 the anti-New Deal Congress cut off all funding for the county planning program, and with it any hope of democratizing agricultural policy. Many of you know the rest of this story: By 1944, Carl Taylor's sociology unit, indeed the entire Bureau of Agricultural Economics, had also suffered political attacks, due largely to two studies in Taylor's division. One in California, by Walter Goldschmidt, found small farms to be more supportive of vibrant rural communities than were industrial farms; the other reported the existence of racial stratification in Mississippi. Such research outraged conservative, anti-reformist politicians and farm leaders who were the enemies of participatory democracy. That's all it took to banish critical social science from the U.S. Department of 
Agriculture (Goldschmidt 1978:453-91; Kirkendall 1966:218-54; Larson and Zimmerman 2003:50-53; Zimmerman 2008).

This "suppression of historical alternatives," to use Barrington Moore's phrase (1978:276-307), resulted in the disappearance of such progressive reform from national policy debates. Congress also closed the BAE's regional offices; no more "Berkeley-itis" for federal sociologists. Most of the rural sociologists thereupon entered the land-grant colleges of agriculture, which also exerted an ideological "chilling effect" on critical social science, as Olaf Larson (2005:31-32) recently recalled. With some exceptions, this politically conservative influence lasted in our discipline for over 30 years. Talk about the long arm of history! This is a consequential story of our very professional lives. These remains of the past continue to affect, and infect, presentday rural sociology.

Now the New Deal was truly over, at least domestically. Carl Taylor, Arthur Raper, and others pursued second careers abroad, working for land reform and rural development in (among other places) Japan, Taiwan, India, Pakistan, Afghanistan, Iran, and Iraq. From the postwar period into the $1960 \mathrm{~s}$, they helped create a new field called "'community development," which seemed suspiciously like the county planning program of the late New Deal (Raper 1953; Sanders 1958:39091, 1985:237-38; Taylor 1960, 1965; Taylor et al., 1965; Voth and Brewster 1989:283-84, 302). This national/local planning program was killed at home but resurrected internationally-but that's another exciting story.

While acknowledging that New Deal democracy was drastically incomplete (denying equal participation to most women, poor people, African Americans, and other minorities), I maintain that the BAE's county planning program and the role that rural sociologists played within it constituted deeply democratizing institutions. They were much different than those aspects of the New Deal that survived World War II, especially today's Farm Service Agency. Finally, I submit that the participatory vision and practices of this progressive New Deal have not been equaled since, at least not in any large-scale public program in the United States.

\section{A New Deal Experiment in Land Reform and Racial Justice}

Probably the greatest failing of New Deal agricultural policy concerned race. Its main program, the Agricultural Adjustment Administration (AAA), systematically discriminated against black farmers, especially tenants and sharecroppers. In the South, the AAA's decentralized 
farmer-committee system set up a "local racial state," with federal power and resources (James 1988). Secretary of Agriculture Henry A. Wallace, like President Franklin D. Roosevelt, almost always caved in to regional racists when push came to shove, a point well established in the historical literature (Daniel 1985; Kirby 1987). Lower-level USDA workers like Carl Taylor and other liberals were less willing to give in, but they still lived and worked within the racist system. This was the dominant agricultural agency and legacy that survived and grew after World War II (Daniel 2007).

But there is a counter-story-an alternative tradition-in the rural New Deal, another democratizing effort. In 1935, President Roosevelt established the Resettlement Administration (RA) as an agency independent of any federal department, the USDA in particular. Consolidating previous New Deal efforts to combat rural poverty, the RA soon became one of the largest and most controversial government agencies. In 1937, it joined the USDA and changed its name to the Farm Security Administration (FSA). Over the next five years, the FSA followed the RA as probably the most class-conscious and least racist agency of the New Deal, culminating with 19,000 workers in regional, state, and 2,300 county offices. Its main program was rural rehabilitation (supervised credit), which ultimately served over 800,000 poor farm families, 20 percent of whom were African American. Other major efforts were national land-use planning (federal purchase and retirement of 10,000,000 submarginal crop acres), three suburban "greenbelt cities," and resettlement of 10,000 needy or displaced workers. The FSA functioned effectively as a "poor people's USDA" for farm workers, sharecroppers, tenants, and small farmers (Baldwin 1968; Kirkendall 1966).

My second instance of how states can democratize civil society also involves Carl Taylor; before joining the BAE, he led the RA's rural resettlement program. One of the agency's smaller programs created about 60 new communities. In a radical land-reform experiment, the RA/FSA elevated dirt-poor sharecroppers and tenant farmers into landowners. In the rural South and elsewhere, most of these planned communities were white, but 13 were black, comprising formerly landless farmers who had worked on white plantations. It would be hard to exaggerate the significance of land ownership in black communities. Since Reconstruction, land had represented the dream of freedom, a measure of security, and achievement of independence from white landlords. The New Deal resettlement communities turned out to engender even greater democratic outcomes. After the FSA withdrew (under congressional duress) in the mid-1940s, the African Americans 
in those communities managed, over the next two decades, to pay off the land and make themselves into middle-class citizens. Further, in the 1960 s, many of them led the civil-rights movement in their locales. Today their descendants carry on the struggle of black farmers and landowners for economic justice (Conkin 1959; Couto 1991; Gilbert and Wood 2004; Grant 2000; Salamon 1979; Wood 2006). ${ }^{5}$ Let me tell you more about this innovative democratic policy experiment and its consequences.

Quite an undertaking, the FSA's community-building process worked like this: Most of the resettlement communities consisted of 100 to 150 families. The USDA bought large plantations and subdivided the land into small family-sized units of 50 to 100 acres, each with at least 40 acres of good cropland. Each settler family received FSA loans to buy a new house, barn, smoke shack, chicken coop, outhouse, water well, tools, and livestock. The diversified farms were designed to provide the family with its sustenance, plus produce a small cash income, usually from cotton. The modest but adequate homes included three to five rooms, depending on family size. Even after 70 years, it is still easy to spot the numerous "little white houses" constructed by the federal government to replace sharecropper shacks. Furthermore, the FSA built community centers, cooperative gins, public schools, and other communal facilities. In addition to the churches that the residents erected themselves, these all quickly became local institutions that helped forge the bonds of community and functioned as the basic building blocks of a blossoming civil society (Gilbert and Wood 2004; Wood 2006).

The resettlement communities provided an undreamed-of standard of living for landless southern farmers (whether white or black). The planned communities also offered two other crucial and radically experimental features: cooperation and supervision. The cooperative enterprises that filled the communities were driven by both ideology and economics. The FSA sought to replace competition and individualism with new values and institutions, and recognized the efficiencies that cooperatives could yield. There seemed to be no end to the kinds of services and facilities to be organized along cooperative lines: pastures, dairies, wood lots, greenhouses, livestock breeding, marketing, retail stores, canneries, gristmills, handicrafts, orchards, cotton gins, blacksmith shops, medical associations, farm equipment, sawmills, warehouses, hatcheries-to name a few. Ideally a certain synergy

\footnotetext{
${ }^{5}$ I have learned a tremendous amount about the resettlement communities from working with Spencer Wood (2006; Gilbert and Wood 2004).
} 
emerged between the individual farm businesses and the larger cooperative ventures. Although many of the others failed, the medical cooperatives were almost universally successful-the nation's first instance of public group health care. Typically each family paid $\$ 2$ a month into a fund that covered all their medical needs. Most resettlement communities had a public-health nurse and a small clinic. Local doctors were usually glad to cooperate although the American Medical Association disapproved (Conkin 1959:196-98, 205; Grey 1999; Holley 1975:132).

All settlers also experienced close expert supervision. On the African American projects, full-time black professionals worked as agricultural managers and home economists, and each family prepared a farm plan and a household plan, both of which received careful periodic monitoring. Essentially, this was an undertaking in practical adult education. Since the time of slavery, landless farmers had been forced to grow mainly cash crops to benefit plantation owners rather than diversifying to meet family needs. The FSA believed that former tenants and sharecroppers usually needed instruction in diversified methods and other modern agricultural practices. Project families were soon producing excess milk, eggs, pork, beef, chickens, and numerous vegetables. In addition, the FSA saw that most poor women could benefit from demonstration classes in sewing, gardening, nutrition, sanitation, child care, home furnishing, and food preservation. While some families chafed under such training and oversight (dissenters were too often labeled "uncooperative"), others thrived. Particularly impressive was the reception of pressure cookers; women held contests for who could can the most fruits and vegetables (Conkin 1959:186213; Holley 1975:122-37). The cooperative and supervisory activities of the resettlement communities often became schools for democracy and experiments in group problem solving-lessons that proved useful another day.

At the same time, the FSA was earning many powerful enemies, both inside and out of government. In 1943, at the behest of the American Farm Bureau Federation and other large-farm groups, the same antiNew Deal Congress that led to the demise of the county planning program gutted the FSA by slashing funds and demanding liquidation of the community projects (Baldwin 1968:365-404; Conkin 1959:21433; Holley 1975:261-78). No one knew for sure what would become of the resettlement communities. Could they make it on their own? In fact, they not only survived but frequently flourished.

Throughout the '50s and ' $60 \mathrm{~s}$, the resettlement communities continued to be instruments of community development and levers 
for social change. Almost all of the project families paid off their government loans-ahead of schedule; they sought to secure their own land, "free and clear," as soon as possible. Many of them achieved economic success through their diversified operations. For example, a long-time academic participant in the Sabine Farms Project in east Texas recalled:

It was indeed inspiring to watch the flow of the crowd from nearby cities and towns like Marshall, Longview, Carthage, and Shreveport who came to the [Sabine Farms Community] Center to engage in the learning and recreational experiences offered there. During the heyday of the Center, thousands of dollars of cucumbers, potatoes, poultry, and hogs were made by these farmers. (Banks 1979:9)

Further, although these participants had been denied formal education themselves, their children often became the first black doctors, lawyers, and professors in the area. The FSA-constructed schools, which usually comprised several buildings including gymnasiums/auditoriums, functioned as extremely important civic institutions for decades. As with Sabine Farms, the projects generally became vibrant strongholds of community life, serving as gathering places for clubs, sports, and celebrations. All of the resettlement sites also housed a number of strong local churches.

Perhaps the most striking example of success occurred during the civil-rights movement of the 1960s. At great personal risk, resettlement farmers led the local initiatives by being the first African Americans to register to vote and by supporting outside civil-rights workers. Some even became the first black elected officials in their regions (Gilbert and Wood 2004; Salamon 1979; Wood 2006). As Wood (2006) details, the most outstanding was the resettlement community of Mileston, Mississippi. With its base of 110 landowning families and strong institutions (a school, cooperative, cotton gin, community store, and churches), Mileston more than met the racist challenges of the 1960s. The resettlement farm families housed Student Non-violent Coordinating Committee workers, led demonstrations in their county seat, organized the state's strongest chapter of the Mississippi Freedom Democratic Party, and expanded their community institutions through President Lyndon B. Johnson's War on Poverty. Some of them won local political office and, from their county, they played a crucial role in electing the first African American since Reconstruction to the Mississippi legislature (Wood 2006). While Mileston may be the most 
dramatic, almost all the black resettlement communities became local strongholds of the civil-rights movement.

The cultural and political struggle continues today. One of the leaders of the contemporary black-farmer movement is Gary Grant, the son of a resettlement family from Tillery, North Carolina. Every year he convenes a National Black Land Loss Summit in Tillery. Grant is also national president of the Black Farmers and Agriculturalists Association, one of the key organizations that sponsored the well-publicized class-action lawsuit against the USDA for racial discrimination. Due to the tireless efforts of Grant and many others, the lawsuit was settled out of court in the largest civil-rights award in American history-over $\$ 1$ billion to date. Further, in June 2008, the Black Congressional Caucus (under pressure from Grant and others) won the expansion of the lawsuit to include many more aggrieved farmers ("Bias Suits by Farmers", 2008).

For these and related reasons, in 2000 the Rural Sociological Society honored Gary Grant with its Distinguished Service to Rural Life Award. Upon that occasion, he reminded us that "throughout the South, land is equal to power. With Black farmers losing land at the rate of 1000 acres per day, the power and independence of Black communities are horribly compromised" (Grant 2000:4). He also challenged us:

Don't use your positions as professors, sociologists, and researchers to run from the pain of racism and struggles you experience in your own communities, some of which may be reminiscent of Tillery. But use your hard fought educations and positions to "act locally." Your skills are priceless to the small, forgotten, isolated, rural communities throughout rural North Carolina [and elsewhere]. (Grant 2000:7)

Gary Grant provides a prominent case of justice-seeking citizens arising from and remaining in the New Deal resettlement communities, but of course he is not the only one. Every resettlement project has its courageous local heroes who have taken on the white power structure, usually to their material detriment. Another example, Dexter Davis from the Mound/Henderson Loop project in northeastern Louisiana, is also the son of a resettlement family. A successful and expanding farmer, he, too, is a political activist, a local and regional leader of the Black Farmers and Agriculturalists Association. In consequence, as Davis has documented in courts of law, he has faced fierce opposition from large white farmers (who seek his land), bankers, attorneys, judges, journalists, law officers, implement dealers, and, not least, USDA officials (Davis 2006). African American farm organizations 
assert that, all over the rural South, local power structures, including county offices of the USDA, continue to discriminate flagrantly against aspiring and successful black farmers (Grant 2000; Zippert 2007). Here Gary Grant's call for assistance, quoted above, raises the issue of rural sociologists' role in progressive social change.

That the contemporary black-farmer movement is strong is itself a testament, in no small measure, to the historic partnership between the New Deal state and African American citizens. Together they built local capacity through crucial institutions of civil society: public schools, community centers, farmer cooperatives, and land ownership. Although the struggles of the civil-rights movement push on in our time, this case highlights the key role of a democratizing state in enabling active citizenship and fomenting social reform (Gilbert and Wood 2004; Wood 2006). This is the historical legacy of the black resettlement communities.

\section{History Lessons for the Future}

Writing history is not a simple or straightforward endeavor. In response to the frequent social-science call (if not claim) to predict the future, William Sewell, Jr. (2006:4) remarks that "scholarly experience convinces us [historians] that it's hard enough to predict the past, let alone the future!" Perhaps that is why two leading theorists of radical democracy hold up agricultural New Deal policies as a model for progressives today, whereas rural sociologists (and historians) tend to criticize the same. Roberto Unger and Cornel West (1998:45-46), referring to rural policy in the 1930s, laud the "partnership between the federal government and the family farmer." They offer "this agrarian alliance" as exemplary of top-down, bottom-up initiatives. Similarly I have re-presented some achievements of the progressive New Deal. My goal is not simply policy replication, for I recognize the vast differences between the historical and political-economic contexts then and now; the "next deal" will not be a carbon copy of the New Deal. Rather, I have used history in an effort "to stimulate and expand the democratic policy imagination,' as Alice O'Connor (2007:17) aptly puts it. I have been "looking backward in order to move forward" (Thompsett 1999:23). Let me now conclude with a few history lessonsfor the future.

Big states and social scientists not only can be but have been agents of democracy. Contrary to most sociologists and historians, I have employed New Deal history to show how a large modern state helped democratize civil society. In the first case, rural sociologists in the 
Bureau of Agricultural Economics used action research to redistribute power and resources in the countryside. In the second, a large federal bureaucracy, the Farm Security Administration, partnered with a class of very poor, rural African Americans. Together they created a more active citizenry and a more equal society. For these endeavors, Richard Couto (1991:306) calls the FSA, along with Reconstruction and Great Society agencies, "heroic bureaucracies." The phrase may sound jarring to our postmodern ears, yet seems appropriate here. I would only extend the compliment to include the BAE. Of course, the topdown aspects of big states can be dangerous, as can elitist social scientists. Rather than partnership, both hold the potential danger of paternalism, or worse (Couto 1991:395). Surely neither the BAE nor the FSA entirely escaped this fate. Yet overall, they advanced democracy in impressive, groundbreaking ways.

As in these reformist agencies, strong democratizing states today can work with participating citizens, and science can join with local knowledge. While those particular programs did not survive World War II, federal rural policy in the mid-1940s could have turned out differently. The progressive New Deal was simply defeated in a specific political struggle. It represents a "historically suppressed alternative" (Moore 1978:376) in terms of democratizing public policy-a loss to history that may be recaptured and reshaped for the future. It is encouraging for us to realize that, next time, democratic forces may win out.

We can renew and reform the democratizing tradition of rural sociology. History can be liberating. The knowledge that large-scale, participatory-action work was actually carried out by rural sociologists (with 150,000 people in thousands of local communities), enables us to envision such a radical possibility again, in our own futures. We are not limited to current points of view but can unshackle our imaginations by drawing from the activist sociologists of the past. Now their story is part of our continuing history, the current chapter of which we are writing. Thus, mining the past emancipates us from the tyranny of the present.

New Deal sociologists exhibited two key traits that we might well aspire to. They thought big, and they were in for the long haul. As visionary social scientists, they sought to change the world-and they did. History reveals how narrow and constrained our own current policy discussions actually are (O'Connor 2007:145). For example, where today do we see such radical public efforts to redistribute wealth and other communitybuilding resources to non-elites? How might we similarly approach, in spirit if not in letter, the urgent problems of our day? In addition, the New Dealers exhibited a creative, long-range view of the consequences 
of apparent policy failure and political defeat. Their own study of history taught that they were part of an ongoing, continuous movement, but that it was a long hard struggle. When Congress ended the county planning program (and with it community delineations) in 1942, these undertakings may have seemed of little consequence. Yet the lessons learned by rural sociologists in that work were soon applied in creating another "CD" - the field of community development that many of us practice today. In other words, what looks like failure may turn out to be success.

History, then, enables us to recover and extend our democratic tradition of rural sociology. Instead of viewing the progressive past merely as spectators, better we claim it as participants, make it our own. Now is our time to exercise our imaginations (policy-wise and otherwise), to expand and improve our sociological tradition. Let us re-source and re-member a more democratizing rural sociology in service to the present and the future.

\section{References}

Baldwin, S. 1968. Poverty and Politics: The Rise and Decline of the Farm Security Administration. Chapel Hill, NC: University of North Carolina Press.

Banks, M.J. 1979. "The Sabine Farms Agricultural Project Experience in Adult Education." Unpublished paper in "Sabine Farms" folder, Harrison County Historical Museum, Marshall, TX.

Beers, H.W., R.M. Williams, Jr., J.S. Page, and D. Ensminger. 1941. Community Land-Use Planning Committees: Organiztion, Leadership, and Attitudes, Garrard County, Kentucky, 1939. Bulletin 417, University of Kentucky Agricultural Experiment Station. Lexington, KY.

Bernstein, R.J. 1992. The New Constellation: The Ethical-Political Horizons of Modernity/ Postmodernity. Cambridge, MA: Massuchetts Institute of Technology Press.

“Bias Suits By Farmers Could Cost Billions." 2008 New York Times. June 29, p. 14.

Bureau of Agricultural Economics, U.S. Department of Agriculture. 1940. "Service and Research in Community Organization." Unpublished report of the Division of Farm Population and Rural Welfare. September. In National Archives and Records Administration II, College Park, MD. Record group 83, entry A1, box 2.

—. 1941. "Annual Report: Division of Farm Population and Rural Welfare." Farm Population and Rural Life Activities 15(October):1-39.

Christie, M.M. 1996. “Carl C. Taylor, 'Organic Intellectual' in the New Deal Department of Agriculture." MS thesis, Department of Rural Sociology, University of Wisconsin, Madison.

Christie, M.M. and J. Gilbert. 1995. "'Sociology on the Spot': Carl Taylor and the Division of Farm Population and Rural Life." Presented at the Twentieth Century Farm Policies Conference, June, College Park, MD.

Cohen, I.J. 1985. "The Underemphasis on Democracy in Marx and Weber." Pp. 274-99 in A Weber-Marx Dialogue, edited by R.J. Antonio and R.M. Glassman. Lawrence, KS: University Press of Kansas.

Conkin, P.K. 1959. Tomorrow a New World: The New Deal Community Program. Ithaca, NY: Cornell University Press.

Couto, R.A. 1991. Ain't Gonna Let Nobody Turn Me Round: The Pursuit of Racial Justice in the Rural South. Philadelphia, PA: Temple University Press. 
Daniel, P. 1985. Breaking the Land: The Transformation of Cotton, Tobacco, and Rice Cultures since 1880. Urbana, IL: University of Illinois Press.

- 2007. "African American Farmers and Civil Rights.' Journal of Southern History 73:3-38.

Davis, D. 2006. Interview with J. Gilbert and M. Sinkewicz, Nov. 14, Tallulah, LA.

Dodson, L.S., D. Ensminger, and R.N. Woodworth. 1940. Rural Community Organization in Washington and Frederick Counties, Maryland. Bulletin 437, University of Maryland Agricultural Experiment Station. College Park, MD.

Ensminger, D. 1940. Diagnosing Rural Community Organization. Extension Bulletin 444, Cornell University Ithaca, NY.

Faulkner, W. 1951. Requiem for a Nun. New York: Random House.

Foucault, M. 1991. "Governmentality." Pp. 87-104 in The Foucault Effect: Studies in Governmentality, edited by G. Burchell, C. Gordon, and P. Miller. Chicago, IL: University of Chicago Press.

Foucault, M. and N. Chomsky. 1997. "Human Nature: Justice versus Power.' Pp. 107-45 in Foucault and His Interlocutors, edited by A.I. Davidson. Chicago, IL: University of Chicago Press.

Gilbert, J. 1996. "Democratic Planning in Agricultural Policy: The Federal/County LandUse Planning Program, 1938-1942.' Agricultural History 70:233-50.

—. 2003. "Low Modernism and the Agrarian New Deal: A Different Kind of State." Pp. 129-46 in Fighting for the Farm, edited by J. Adams. Philadelphia, PA: University of Pennsylvania Press.

- 2008. "Rural Sociology and Democratic Planning in the Third New Deal." Agricultural History 82:421-38.

Gilbert, J. and S.D. Wood. 2004. "Securing the Future by Securing the Land: The New Deal State and Local African Americans Remake Civil Society in the Rural South, 1935-2003.' Presented at the annual meeting of the Rural Sociological Society, August, Sacremento, CA.

Goldschmidt, W. 1978. As You Sow: Three Studies in the Social Consequences of Agribusiness. Montclair, NJ: Allanheld, Osmun.

Gordon, C. 1991. "Governmental Rationality." Pp. 1-51 in The Foucault Effect: Studies in Governmentality, edited by G. Burchell, C. Gordon, and P. Miller. Chicago, IL: University of Chicago Press.

Grant, G. 2000. "Fighting for Justice.” The Rural Sociologist 20(4):3-7.

Grey, M.R. 1999. New Deal Medicine: The Rural Health Programs of the Farm Security Administration. Baltimore, MD: Johns Hopkins University Press.

Holley, D. 1975. Uncle Sam's Farmers: The New Deal Communities in the Lower Mississippi Valley. Urbana, IL: University of Illinois Press.

James, D. 1988. "The Transformation of the Southern Racial State.” American Sociological Review 53:191-208.

Kirby, J.T. 1987. Rural Worlds Lost: The American South, 1920-1960. Baton Rouge, LA: Louisiana State University Press.

Kirkendall, R.S. 1966. Social Scientists and Farm Politics in the Age of Roosevelt. Columbia, MO: University of Missouri Press.

Kloppenburg, J.T. 1994. "Democracy and Disenchantment: From Weber and Dewey to Habermas and Rorty." Pp. 69-90 in Modernist Impulses in the Human Sciences, edited by D. Ross. Baltimore, MD: Johns Hopkins University Press.

Larson, O.F. 2005. "A Conversation with Olaf Larson," conducted by J.N. Zimmerman. The Rural Sociologist 25(4):30-32.

Larson, O.F., R.M. Williams, Jr., and R.C. Wimberley. 1999. "Dismissal of a Sociologist: The AAUP Report on Carl C. Taylor.'” Rural Sociology 64:533-53.

Larson, O.F. and J.N. Zimmerman. 2003. Sociology in Government: The Galpin-Taylor Years in the U.S. Department of Agriculture, 1919-1953. University Park, PA: Pennsylvania State University Press.

Loomis, C.P. and D. Ensminger. 1942. "Governmental Administration and Informal Local Groups.’' Applied Anthropology 1(2):41-62. 
Loomis, C.P., D. Ensminger, and J. Woolley. 1941. "Neighborhoods and Communities in County Planning." Rural Sociology 6:339-41.

Mills, C.W. 1959. The Sociological Imagination. New York: Oxford University Press.

Moore, B., Jr. 1978. Injustice: The Social Bases of Obedience and Revolt. White Plains, NY: M.E. Sharpe.

Niebuhr, H.R. 1941. The Meaning of Revelation. New York: Macmillan.

O'Connor, A. 2007. Social Science for What? New York: Russell Sage.

Pelikan, J. 1984. The Vindication of Tradition. New Haven, CT: Yale University Press.

Raper, A.F. 1943. Tenants of the Almighty. New York: Macmillan.

. 1953. "Rural Sociologists and Foreign Assignments." Rural Sociology 18:264-66.

Rorty, R. 1998. Achieving Our Country: Leftist Thought in Twentieth-Century America. Cambridge, MA: Harvard University Press.

Salamon, L.M. 1979. "The Time Dimension in Policy Evaluation: The Case of New Deal Land- Reform Experiments."' Public Policy 27:129-83.

Sanders, I.T. 1958. The Community. New York: Ronald Press.

1985. "The Social Reconnaissance Method of Community Study." Research in Rural Sociology and Development 2:235-55.

Sanders, I.T. and D. Ensminger. 1940. Alabama Rural Communities. Bulletin 33, No. 1A, Alabama College. Montevallo, AL.

Sanderson, D. 1943. "Sociology a Means to Democracy." American Sociological Review 8:1-9.

Scott, J.C. 1998. Seeing like a State: How Certain Schemes to Improve the Human Condition Have Failed. New Haven, CT: Yale University Press.

Sewell, W.H., Jr. 2006. "History as a Social Science Discipline: Remarks on the Occasion of the Dedication of the William H. Sewell Social Science Building at the University of Wisconsin." Unpublished manuscript.

Summers, M. 2003. "The New Deal Farm Programs: Looking for Reconstruction in American Agriculture." Pp. 147-59 in Fighting for the Farm, edited by J. Adams. Philadelphia, PA: University of Penn. Press.

Taylor, C.C. 1937a. "Sociology on the Spot." Rural Sociology 2:373-81.

—. 1937b. "Social Research." Unpublished memo to M.L. Wilson, May 28. In M.L. Wilson Papers, Folder A2, Burlingame Special Collections, Montana State University Libraries, Bozeman, MT.

- 1938. "Comprehensive Yet Logical and Democratic Approaches to Group Planning and Social Planning." Discussion [paper] presented to the Rural Sociological Society annual meeting, December. In Box 1, Carl C. Taylor Papers, Rare and Manuscript Collections, Kroch Library, Cornell University, Ithaca, NY.

—. 1940. "Social Theory and Social Action." Rural Sociology 5:17-31.

. 1941a. "Social Science and Social Action in Agriculture." Social Forces 20:154-59. - 1941b. "The Implementation of Democracy." Presented to the American Sociological Society, December. In Box 1, Carl C. Taylor Papers, Rare and Manuscript Collections, Kroch Library, Cornell University, Ithaca, NY.

- 1943. Letter to J.S. Page, December 9. In Box 36, Carl C. Taylor Papers, Rare and Manuscript Collections, Kroch Library, Cornell University, Ithaca, NY.

- 1947. "Sociology and Common Sense." American Sociological Review 12:1-9.

. 1960. "Early Rural Sociological Research in Latin America." Rural Sociology 25:1-8.

1965. "The Development of Rural Sociology Abroad." Rural Sociology 30:462-73.

- N.d. [ca. 1940]. "The ABC's of the Democratic Process." Unpublished manuscript. In Box 1, Carl C. Taylor Papers, Rare and Manuscript Collections, Kroch Library, Cornell University, Ithaca, NY.

Taylor, C.C., D. Ensminger, H.W. Johnson, and J. Joyce. 1965. India's Roots of Democracy: A Sociological Analysis of Rural India's Experience in Planned Development since Independence. Bombay: Orient Longmans.

Thompsett, F.H. 1999. Living with History. Boston, MA: Cowley.

Unger, R.M. and C. West. 1998. The Future of American Progressivism: An Initiative for Political and Economic Reform. Boston, MA: Beacon. 
Voth, D.E. and M. Brewster. 1989. "An Overview of International Community Development." Pp. 280-306 in Community Development in Perspective, edited by J.A. Christenson and J.W. Robinson. Ames, IA: Iowa State University Press.

Wakeley, R.E. 1941. "Rural Planning: Its Social and Organizational Aspects." Rural Sociology 6:62-67.

Weber, M. 1978. Economy and Society, vol. 2. Berkeley, CA: University of California Press.

Williams, R. 2005. Why Study the Past? Grand Rapids, MI: Eerdmans.

Wood, S.D. 2006. "The Roots of Black Power: Land, Civil Society, and the State in the Mississippi Delta, 1935-1968." PhD dissertation, Department of Sociology, University of Wisconsin, Madison.

Zimmerman, J.N. 2008. "Voices from the Past, Lessons for the Future." Equal Opportunities International 27:132-47.

Zippert, J. 2007. "Statement of John Zippert on Behalf of the Federation of Southern Cooperatives/Land Assistance Fund and the Rural Coalition/Coalición Rural to the U.S. House of Representatives Committee on Agriculture, Subcommittee on Conservation, Credit, Energy, and Research." March 27. Retrieved September 22, 2008 (http://www.ruralco.org/content/ZippertTestimony.pdf). 